\title{
Polecenia obowiązujące i akty kierownictwa w dobie epidemii. Szansa czy zagrożenie?
}

\author{
Binding orders and acts of management in the epidemic era. \\ An opportunity or a threat? \\ Действующие приказы и акты управления в период эпидемии. \\ Возможность или угроза?
}

\author{
MARIUSZ SZYRSKI \\ Dr hab., Uniwersytet Kardynała Stefana Wyszyńskiego w Warszawie \\ e-mail:m.szyrski@uksw.edu.pl, https://orcid.org/0000-0001-8536-4054
}

\begin{abstract}
Streszczenie: $W$ artykule zostało omówione pojęcie aktów kierownictwa w odniesieniu do sytuacji epidemicznej, w szczególności poprzez zestawienie z formami działania administracji publicznej. Główny nacisk położono na akt kierownictwa o nazwie „polecenie obowiązujące”, która to forma pojawia się w nowych przepisach związanych ze zwalczaniem skutków rozprzestrzeniania się koronawirusa. Ukazano podstawy prawne wydawania aktów kierownictwa, w ostatnim czasie oddziałujące także na sferę zewnętrzną administracji publicznej. Główne pytanie badawcze sprowadza się do zakreślenia obecnych granic przedmiotowych i podmiotowych aktów kierownictwa (poleceń obowiązujących), tak w zakresie stanowienia, jak i stosowania regulacji prawnej. Rozważania odniesiono przede wszystkim do regulacji prawnej wynikającej z ustawy z dnia 2 marca 2020 r. o szczególnych rozwiązaniach związanych z zapobieganiem, przeciwdziałaniem i zwalczaniem COVID-19, innych chorób zakaźnych oraz wywołanych nimi sytuacji kryzysowych.
\end{abstract}

Słowa kluczowe: kierownictwo, COVID-19, koronawirus, źródła prawa

Summary: The aim of the article is to return to the concept of acts of management and to compare them with the epidemic situation, in particular with the forms of public administration activities. The main emphasis will be on a management act called "binding order", a form that appears in the new regulations related to countering the effects of the coronavirus. Therefore, it will be important to show the legal basis for issuing management acts, which have also recently had a serious and deep impact on the external sphere of public administration. The main research question that will be discussed is what are the current objective and subjective boundaries of management acts (binding orders) - both in terms of making and applying legal regulations. The basic background for considerations will be the legal regulation resulting from the Act of March 2, 2020, on special solutions related to the prevention, prevention and combating of COVID-19, other infectious diseases, and the crisis situations caused by them.

Key words: Management, COVID-19, Coronavirus, law sources

Резюме: В статье обсуждается концепция актов управления применительно к текущей эпидемической ситуации, в частности, путем сравнения с формами действий государственной администрации в рамках кризисного управления. Основной акцент был сделан на акте управления под названием «действующий приказ», форма которого фигурирует в новых нормативных актах, связанных с борьбой с последствиями распространения коронавируса. Была представлена правовая основа для издания исполнительных актов, которые в последнее время затрагивают и внешнюю сферу государственного управления. Основной вопрос исследования сводится к современным границам субъективных и объективных актов управления (действующих приказов), как с точки зрения установления, так и применения правовых норм. Рассуждения были отнесены, прежде всего, к правовому регулированию, вытекающему из Закона 
«Об особых решениях, связанных с предотвращением, противодействием и борьбой с COVID-19, другими заразными болезнями, а также с вызванными ими кризисными ситуациями» от 2 марта 2020 года.

Ключевые слова: управление, COVID-19, коронавирус, источники права

\section{Wstęp}

Kierownictwo to relacja, która nadal (mając na uwadze inne stosunki administracyjno-prawne) jest najrzadziej opisywana, a w związku z tym także najmniej rozpoznana z punktu widzenia naukowego. Fascynacja miękkimi formami działania administracji, a także formami alternatywnego rozwiązywania sporów powoduje, że zagadnienia związane $\mathrm{z}$ kierownictwem są odsuwane na dalszy plan na rzecz analizy takich zjawisk i pojęć jak np. koordynacja, czy kooperacjaํ. Tymczasem stan epidemii koronawirusa (stan epidemii jest określony przez przepisy jako sytuacja prawna wprowadzona na danym obszarze w związku z wystąpieniem epidemii w celu podjęcia określonych w ustawie działań przeciwepidemicznych i zapobiegawczych dla zminimalizowania skutków epidemii²) pokazuje, że relacje związane $\mathrm{z}$ kierownictwem $\mathrm{w}$ administracji publicznej (w tzw. jej sferze wewnętrznej) są fundamentem procesu wydawania aktów administracyjnych oraz aktów normatywnych. Epidemia koronawirusa stała się przyczyną wprowadzenia nowej regulacji prawnej powodującej istotne zmiany w relacjach pomiędzy podmiotami administrującymi. W związku z pojawieniem się sytuacji kryzysowej, jaką jest epidemia, uchwalono nowe przepisy ustawowe oraz przyjęto akty wykonawcze. Uzasadnienia do projektów aktów normatywnych wskazują, że przyjęte rozwiązania mają jedynie charakter incydentalny i czasowy, np. pierwotna wersja ustawy z dnia 2 marca 2020 r. o szczególnych rozwiązaniach związanych z zapobieganiem, przeciwdziałaniem i zwalczaniem COVID-19, innych chorób zakaźnych oraz wywołanych nimi sytuacji kryzysowych ${ }^{3}$. Pojawia się więc pytanie, czy rzeczywiście tak będzie i jaki jest zamysł prawodawcy.

Celem tego artykułu jest powrót do pojęcia aktów kierownictwa i zestawienie ich z formami działania administracji publicznej przyjętymi w regulacji prawnej odnoszącej się do zwalczania pandemii koronawirusa. Analizie zostanie poddana forma

1 R. Stankiewicz, Koordynacja w prawie administracyjnym, Warszawa 2019.

2 Art. 2 pkt 22 ustawy z dnia 5 grudnia 2008 r. o zapobieganiu oraz zwalczaniu zakażeń i chorób zakaźnych u ludzi, tekst jednolity: Dz. U. z 2020 r. poz. 1845.

3 Ustawa z dnia 2 marca 2020 r. o szczególnych rozwiązaniach związanych z zapobieganiem, przeciwdziałaniem i zwalczaniem COVID-19, innych chorób zakaźnych oraz wywołanych nimi sytuacji kryzysowych, Dz. U z 2020 r. poz. 374. 
prawna określona przez prawodawcę jako „polecenie obowiązujące”. Istotne będzie ukazanie podstaw prawnych do wydawania tego typu aktów. Podstawowym pytaniem badawczym, wokół którego będą toczone rozważania, jest to, jakie są granice przedmiotowe i podmiotowe poleceń obowiązujących wydawanych na podstawie art. 11 h ustawy z dnia 2 marca 2020 r. o szczególnych rozwiązaniach związanych z zapobieganiem, przeciwdziałaniem i zwalczaniem COVID-19, innych chorób zakaźnych oraz wywołanych nimi sytuacji kryzysowych (dalej: ustawa COVID-19) ${ }^{4}$.

\section{Pojęcie kierownictwa i aktów kierownictwa}

Konstrukcja polecenia obowiązującego występującego w art. 11h ustawy COVID-19 prowadzić będzie analizę w stronę pojęcia kierownictwa i aktów kierownictwa. Spróbujmy dokonać wstępnej analizy tych pojęć.

$\mathrm{W}$ monografii pt. Kierownictwo $w$ samorządzie terytorialnym - analiza administracyjnoprawna wskazano, że bardzo trudne jest stworzenie spójnych i wyczerpujących definicji legalnych dla pojęć teoretycznych zaczerpniętych $\mathrm{z}$ teorii prawa administracyjnego i nauki o administracji publicznej. ${ }^{5}$ W obrębie tego opracowania za immanentne cechy kierownictwa uznano m.in., że: 1) kierownictwo to określenie nazwy i typu relacji między podmiotami w administracji publicznej, a z punktu widzenia językowego jest to pojęcie należące do tej samej kategorii co nadzór, kontrola oraz koordynacja; 2) w kierownictwie zawierają się elementy powiązań prawnych o charakterze pozaorganizacyjnym, takich jak: nadzór, kontrola i koordynacja; 3) struktura administracji publicznej oparta na konstrukcji kierownictwa gwarantuje funkcjonowanie danej organizacji ${ }^{6}$. Kierownictwo jawi się więc jako pewna relacja związana ze stosunkami administracyjno-prawnymi, w ramach której występuje element podporządkowania. W 2016 r. pojawiła się monografia na temat pojęcia kierownictwa w prawie administracyjnym autorstwa W. Góralczyka jr. Autor ten zaproponował własną definicję kierownictwa i stwierdził on m.in., że kierownictwo stanowi typową sytuację administracyjnoprawną organu

4 Ustawa z dnia 2 marca 2020 r. o szczególnych rozwiązaniach związanych z zapobieganiem, przeciwdziałaniem i zwalczaniem COVID-19, innych chorób zakaźnych oraz wywołanych nimi sytuacji kryzysowych, tekst jednolity: Dz. U. z 2020 r. poz. 1842.

5 M. Szyrski, Kierownictwo w samorzadzie terytorialnym. Analiza administracyjnoprawna, Warszawa 2015, s. 90 .

6 Tamże. 
administrującego ${ }^{7}$. Zdaniem tego autora $-\mathrm{w}$ ramach kierownictwa podmiot kierujący może wobec podmiotów administrowanych, niekorzystających z prawnie zapewnionej samodzielności, stosować liczne i różnorodne władcze środki oddziaływania. Środki te nie muszą być określone ustawowo, choć nie mogą być z ustawą sprzeczne, a ich dobór zależy od woli organu sprawującego kierownictwo. Mogą być stosowane także środki o charakterze otwartym ${ }^{8}$. W ten sposób w doktrynie dokonano pewnej klasyfikacji aktów kierownictwa i zestawiono je $\mathrm{z}$ dotychczasowymi instytucjami prawa administracyjnego - jak chociażby władztwo administracyjne.

Kierownictwo odnosi się zatem do takiej przestrzeni, w której istnieje możliwość stosowania różnorodnych (czasem nienazwanych) środków - aktów kierownictwa. Jak słusznie wskazuje J. Zimmermann, trudne jest znalezienie cech wspólnych wszystkich aktów wewnętrznych, ogromne ich zróżnicowanie zaczyna się od samego nazewnictwa, które jest tu bardzo różne $e^{9}$. Akty te nie muszą być określane ustawowo, ponieważ wynikają z tzw. normy ustrojowej. Wskazuje się, że w zależności od określonego przez normy regulujące właściwość statusu prawnego podmiotu i jego miejsca w układzie - aktualizuje się dany obowiązek (zadanie) - a może to być obowiązek kierowania, nadzorowania, koordynacji, współdziałania, kontroli ${ }^{10}$. Zdolność do wydawania aktów kierownictwa należy więc w aspekcie tych rozważań uznać za kluczową problematykę. Pojawia się pytanie o granice związane z możliwością wydania tego rodzaju aktów, a także następnie o powinności wynikające z faktu ich wydania. W szczególności ma to znaczenie dla takich aktów kierownictwa, które w pewien sposób mogą dotyczyć sytuacji prawnej podmiotów spoza administracji publicznej. Oznacza to, że akty kierownictwa, w tym polecenia służbowe, kwalifikuje się - często bez głębszej analizy - jako immanentny element stosunku kierownictwa - wynikający przede wszystkim z relacji pracowniczych i stosunku służbowego. Tymczasem - co zostanie wskazane w tym artykule, może zaistnieć inna sytuacja, w której nie będzie istniał stosunek służbowy.

$\mathrm{W}$ analizie aktów kierownictwa bardzo istotnym rozgraniczeniem jest podział na akty indywidualne i generalne. Wskazuje się, że czym innym jest prawo wewnętrzne o charakterze organizacyjnym ( $w$ tym znaczeniu również generalnym), a czym innym jest indywidualne polecenie przełożonego ${ }^{11}$. Akty kierownictwa

\footnotetext{
7 W. Góralczyk jr, Kierownictwo w prawie administracyjnym, Warszawa 2016, s. 25.

8 Tamże.

9 J. Zimmermann, Prawo administracyjne, Warszawa 2012, s. 86.

10 Z. Cieślak, Zbiory zachowań $w$ administracji państwowej. Zagadnienia podstawowe, Warszawa 1992, s. 66 .

11 Wyrok SN - Izba Pracy, Ubezpieczeń Społecznych i Spraw Publicznych z dnia 19 października 2017 r., II PK 292/16, Legalis nr 1715387.
} 
o charakterze indywidualnym przyjmują najczęściej formułę polecenia służbowego i wydawane są na podstawie Kodeksu pracy ${ }^{12}$ w ramach stosunku pracy. Tutaj szczególne znaczenie mają tzw. pragmatyki służbowe dla poszczególnych grup zawodowych. Drugą obszerną grupą aktów kierownictwa są akty o charakterze generalnym, które adresowane są do większej liczby adresatów w ramach struktury scentralizowanej. Są to różnego rodzaju zarządzenia oraz uchwały i tego typu akty rodzą najwięcej problemów w doktrynie prawa, ponieważ są one często nienazwane i mogą przyjmować różne formy.

Zacznijmy od pierwszej grupy. Zgodnie $\mathrm{z}$ art. 77 ustawy o służbie cywilnej ${ }^{13}$ członek korpusu służby cywilnej jest obowiązany wykonywać polecenia służbowe przełożonych. Podobną regulację odnajdziemy w art. 18 ustawy o pracownikach urzędów państwowych ${ }^{14}$ oraz art. 25 ustawy o pracownikach samorządowych ${ }^{15}$. Artykuły te mają bezpośredni związek z treścią art. 22 Kodeksu pracy, zgodnie z którym przez nawiązanie stosunku pracy pracownik zobowiązuje się do wykonywania pracy określonego rodzaju na rzecz pracodawcy i pod jego kierownictwem oraz w miejscu i czasie wyznaczonym przez pracodawcę, a pracodawca - do zatrudniania pracownika za wynagrodzeniem. Jak wskazuje się w doktrynie, przez „kierownictwo pracodawcy” należy rozumieć możliwość wydawania wiążących poleceń w zakresie wykonywania pracy, przede wszystkim sposobu jej wykonywania. Wynika $\mathrm{z}$ niego obowiązek podporządkowania się przez pracowników przełożonym, pewnego rodzaju hierarchiczność występująca w związku z istnieniem stosunku pracy. Chodzi o możliwość zlecania "na bieżąco” pracy (zadań) do wykonania ${ }^{16}$. Wskazane wyżej akty kierownictwa wynikają z hierarchicznego podporządkowania i stosunku pracy. Przedmiotowo nie powinny wykraczać poza zakres umowy o pracę, a właściwe regulacje związane z poleceniami niezgodnymi z prawem lub innego rodzaju zostały przez ustawodawcę wskazane w ustawie.

Druga grupa aktów kierownictwa jest bardziej zróżnicowana i przysparza wiele problemów interpretacyjnych. W dużej części przypadków podstawa prawna do wydania aktu kierownictwa o charakterze generalnym znajdować się będzie w ustawowym prawie ustrojowym. Taka kompetencja jest związana z uprawnieniem do

12 Ustawa z dnia 26 czerwca 1974 r. - Kodeks pracy, tekst jednolity: Dz. U. z 2020 r. poz. 1320.

13 Ustawa z dnia 21 listopada 2008 r. o służbie cywilnej, tekst jednolity: Dz. U. z 2020 r. poz. 265 z późn. zm.

14 Ustawa z dnia 16 września 1982 r. o pracownikach urzędów państwowych, tekst jednolity: Dz. U. z 2020 r. poz. 537.

15 Ustawa z dnia 21 listopada 2008 r. o pracownikach samorządowych, tekst jednolity: Dz. U. z 2019 r., poz. 1282.

16 M. Rotkiewicz, Ustawa o służbie cywilnej. Komentarz, 2018 [baza danych Legalis], Komentarz do art. 77. 
wydawania prawa wewnętrznego, co kieruje analizę w stronę przepisów konstytucyjnych. Wyjdźmy od treści art. 93 ust. 1 Konstytucji $\mathrm{RP}^{17}$, który przewiduje, że uchwały Rady Ministrów oraz zarządzenia Prezesa Rady Ministrów i ministrów mają charakter wewnętrzny i obowiązują tylko jednostki organizacyjnie podległe organowi wydającemu te akty. Dalej materia konstytucyjna stanowi, że zarządzenia są wydawane tylko na podstawie ustawy i nie mogą one stanowić podstawy decyzji wobec obywateli, osób prawnych oraz innych podmiotów. Artykuł 93 Konstytucji RP wyznacza katalog otwarty wewnętrznych źródeł prawa. Jak słusznie stwierdza P. Tuleja, pod pojęciem podległości organizacyjnej, o której mowa w art. 93, należy rozumieć stosunek prawny, w którym jedna ze stron ma status podmiotu sprawującego funkcję władzy publicznej. Postacią podległości organizacyjnej jest w szczególności tzw. hierarchiczne podporządkowanie $\mathrm{w}$ ramach struktur administracji publicznej (np. administracji rządowej), wyrażające się podległością służbową i zależnością osobową ${ }^{18}$. Prawo wewnętrzne - w rozumieniu art. 93 ust. 1 Konstytucji RP - obowiązuje tylko jednostki organizacyjne podległe organowi wydającemu te akty. Pojęcie podległości organizacyjnej nie jest zdefiniowane prawnie. Jak jednak wskazuje się w doktrynie, jest to więź ustrojowo-prawna, w której podmioty organizacyjnie nadrzędne mogą ingerować $\mathrm{w}$ działania podmiotów podporządkowanych za pomocą dowolnie dobranych środków, odpowiednich do określonej sytuacji. Cecha ta oznacza obowiązywanie aktów w układzie stosunków nadrzędności i podporządkowania oraz uzasadnia nazwanie ich aktami, które „mają charakter wewnętrzny” ${ }^{19}$. Na podstawie dorobku doktryny i orzecznictwa można wskazać pewne typy relacji między podmiotami, które uzasadniają traktowanie ich jako „podległości organizacyjnej” w rozumieniu art. 93 ust. 1 Konstytucji $\mathrm{RP}^{20}$. Ta typologia przedstawia się następująco: 1) do omawianej kategorii należy zaliczyć tzw. hierarchiczne podporządkowanie; zostało ono przez Trybunał Konstytucyjny zdefiniowane jako jednostronna zależność organu niższego stopnia od organu stopnia wyższego lub podmiotu podległego od podmiotu zwierzchniego; 2) w orzecznictwie wyróżniono również tzw. więź ustrojowo-prawną, polegającą na tym, że podmioty organizacyjnie nadrzędne mogą ingerować w przedmiotowo i konstytucyjnie określonym zakresie, $\mathrm{w}$ działania podmiotów podporządkowanych

17 Konstytucja Rzeczypospolitej Polskiej z dnia 2 kwietnia 1997 r., Dz. U. z 1997 r. Nr 78, poz. 483 z późn. zm.

18 P. Tuleja, Konstytucja Rzeczypospolitej Polskiej. Komentarz, 2019 [baza danych LEX], Komentarz do art. 93.

19 M. Haczkowska, w: Konstytucja Rzeczypospolitej Polskiej. Komentarz, red. M. Haczkowska, 2014 [baza danych LEX], Komentarz do art. 93.

20 M. Wiącek, w: Konstytucja RP. Komentarz, red. M. Safjan, L. Bosek, 2016 [baza danych Legalis], Komentarz do art. 93. 
w każdej ich fazie i w zakresie, za pomocą dowolnie dobranych dla danej sytuacji środków; 3) została stworzona koncepcja tzw. podległości funkcjonalnej, która mieści się w pojęciu „podległości organizacyjnej”, a tym samym daje legitymację do wydawania aktów prawa wewnętrznego; ta kategoria została przez Trybunał Konstytucyjny przyjęta np. na określenie relacji między NBP a prywatnymi bankami ${ }^{21}$. Doktryna $\mathrm{z}$ otwartym zakresem podmiotowym i przedmiotowym wynikającym z treści art. 93 Konstytucji RP ma pewien problem. Do tej grupy zalicza się bowiem nie tylko akty wydawane przez administrację rządową - wskazane expressis verbis w art. 93 ust. 1 Konstytucji RP, ale także np. akty wydawane przez podmioty należące do władzy ustawodawczej (np. regulamin pracy Sejmu) ${ }^{22}$, czy podmioty należące do administracji zespolonej. Art. 93 ust. 1 Konstytucji RP jest zatem związany z uprawnieniem do wydawania aktów kierownictwa dla różnych podmiotów i dla aktów o różnej nazwie - nie tylko dla uchwał Rady Ministrów czy zarządzeń Prezesa Rady Ministrów.

\section{Polecenia obowiązujące w zarządzaniu epidemią}

Czas epidemii koronawirusa i sytuacja związana z zarządzaniem stanem epidemii każe przyjrzeć się regulacji dotyczącej wydawania form działania administracji publicznej i zestawienia ich $\mathrm{z}$ formami właściwymi dla kierownictwa, o których była mowa w pierwszej części tego opracowania.

Przyjrzyjmy się szczegółowej regulacji prawnej wynikającej z prawa materialnego, tj. art. 11h ustawy COVID-19 (wcześniej art. 11). Ustawa ta jest jednym z kluczowych aktów normatywnych związanych z przeciwdziałaniem epidemii koronawirusa w Polsce. Od momentu jej uchwalenia doczekała się ona już kilku nowelizacji, a nawet już po pół roku jej obowiązywania - tekstu jednolitego. Obowiązujący art. $11 \mathrm{~h}$ tej ustawy wprowadza istotne wyjątki w relacjach pomiędzy podmiotami administrującymi (rozumianymi szeroko, nie tylko jako organami) w administracji publicznej.

W art. 11 h ust. 1 ustawy COVID-19 postanowiono, że w okresie obowiązywania stanu zagrożenia epidemicznego albo stanu epidemii, ogłoszonego z powodu COVID-19, oraz w okresie 3 miesięcy po ich odwołaniu wojewoda może wydawać polecenia obowiązujące wszystkie organy administracji rządowej działające

21 Tamże.

22 Zob. I. Malinowska, Źródła prawa w Konstytucji RP z 1997 roku, Przegląd Sejmowy 2017, nr 6, s. $282-304$. 
w województwie, państwowe osoby prawne, organy samorządu terytorialnego, samorządowe osoby prawne oraz samorządowe jednostki organizacyjne nieposiadające osobowości prawnej. O wydanych poleceniach wojewoda niezwłocznie informuje właściwego ministra. Przepis ten wyraża daleko idące uprawnienie organu administracji rządowej (wojewody) w stosunku do innych podmiotów, których katalog nie został uszczegółowiony, mimo zastosowania formy katalogu zamkniętego (o czym świadczy np. określenie: samorządowe jednostki organizacyjne nieposiadające osobowości prawnej). O otwartym zakresie tego wyliczenia świadczy treść ust. 2, gdzie wskazano, że minister właściwy do spraw zdrowia może, z własnej inicjatywy lub na wniosek wojewody, wydawać polecenia obowiązujące podmioty inne niż wymienione w ust. 1, w szczególności osoby prawne i jednostki organizacyjne nieposiadające osobowości prawnej oraz przedsiębiorców, a także (na mocy nowelizacji z końca 2020 r. $^{23}$ ) państwowe jednostki organizacyjne posiadające osobowość prawną. Ten katalog jest otwarty (na co wskazuje słowo „w szczególności”) i dotyczy także podmiotów spoza administracji publicznej (przedsiębiorców).

W tym miejscu należy wyraźnie zaznaczyć, że w obrębie art. 11h ustawy COVID-19 w jednej jednostce redakcyjnej zawarto przepisy, które odnoszą się zupełnie do dwóch różnych przestrzeni, a mianowicie jest tu mowa o poleceniach obowiązujących wydawanych podmiotom $\mathrm{z}$ zakresu administracji publicznej oraz o poleceniach wydawanych przedsiębiorcom (art. 11h ust. 2 pkt 1). Tego typu zabieg legislacyjny jest niewłaściwy, ponieważ rodzi kontrowersje interpretacyjne, o których będzie mowa niżej.

Regulacja prawna przewidziana $\mathrm{w}$ art. 11h ustawy COVID-19 jest zbliżona do obowiązującej (a krytykowanej w doktrynie ${ }^{24}$ ) normy wynikającej z art. 25 ustawy z dnia 23 stycznia 2009 r. o wojewodzie i administracji rządowej w województwie ${ }^{25}$, gdzie znajduje się sformułowanie, że wojewoda może wydawać polecenia obowiązujące wszystkie organy administracji rządowej działające w województwie, a w sytuacjach nadzwyczajnych, o których mowa w art. 22 pkt 2 tej ustawy, obowiązujące również organy samorządu terytorialnego. Wskazuje się, że polecenia te są aktami zbliżonymi swoim charakterem do poleceń służbowych, które wydawane są na podstawie przepisów pragmatyk służbowych jako indywidualne akty przełożonych

23 Ustawa $\mathrm{z}$ dnia 27 listopada 2020 r. o zmianie niektórych ustaw $\mathrm{w}$ celu zapewnienia w okresie ogłoszenia stanu zagrożenia epidemicznego lub stanu epidemii kadr medycznych, Dz. U. z 2020 r. poz. 2401.

24 Zob. P. Sadowski, Relacje administracji samorzadowej i rządowej w świetle kompetencji marszałka województwa i wojewody, Przegląd Prawa Publicznego 2019, nr 5, s. 76-86.

25 Ustawa z dnia 23 stycznia 2009 r. o wojewodzie i administracji rządowej w województwie, tekst jednolity: Dz. U. z 2019 r. poz. 1464. 
adresowane do podwładnych, cechujące się najwyższym stopniem imperatywności; za pomocą takiego polecenia przełożony jednostronnie może określić zarówno cel (oczekiwany rezultat), jak i termin rozpoczęcia i zakończenia oraz szczegółową procedurę działania podwładnego ${ }^{26}$. W tym akcie prawnym brak jest natomiast określenia formy prawnej polecenia, która $\mathrm{w}$ ustawie COVID-19 przyjęła formę „aktu administracyjnego”. Zaznacza się, że ustawa o wojewodzie i administracji rządowej w województwie zawiera dość kontrowersyjne rozwiązania, wprowadzając podległość pomiędzy organami jednostek samorządu terytorialnego, a także między nimi a organami administracji rządowej ${ }^{27}$. Podkreśla się, że samorząd stanowi administrację zdecentralizowaną, wykluczającą hierarchiczne podporządkowanie pomiędzy tymi organami ${ }^{28}$. Na przykładzie relacji w powiecie $\mathrm{w}$ doktrynie stwierdza się jednoznacznie, że ustawowa kompetencja dotycząca wydawania przez starostę wiążących poleceń organom wykonawczym gmin $z$ obszaru powiatu jest sprzeczna z Konstytucją RP, w świetle której w odniesieniu do jednostek samorządu terytorialnego nie ma zastosowania zasada podporządkowania ${ }^{29}$. Prawdopodobnie w tym przypadku celem ustawodawcy była pewna forma ustalenia zasad zespolenia w samorządzie terytorialnym, jednak forma ta wydaje się wykraczać poza ustalone konstytucyjnie zasady organizacji administracji publicznej.

W art. $11 \mathrm{~h}$ ust. 4 ustawy COVID-19 postanowiono, że polecenia, o których tu mowa, są wydawane w związku z przeciwdziałaniem COVID-19 w drodze decyzji administracyjnej i podlegają natychmiastowemu wykonaniu $\mathrm{z}$ chwilą ich doręczenia lub ogłoszenia oraz nie wymagają uzasadnienia. Mogą one być wydawane ustnie, pisemnie $\mathrm{w}$ formie adnotacji, telefonicznie, za pomocą środków komunikacji elektronicznej w rozumieniu art. 2 pkt 5 ustawy z dnia 18 lipca 2002 r. o świadczeniu usług drogą elektroniczną lub za pomocą innych środków łączności ${ }^{30}$.

Brak jest w ustawie COVID-19 zakresu przedmiotowego niniejszego „polecenia obowiązującego". Ustawa posługuje się jedynie stwierdzeniem, że polecenia te mogą być wydawane w związku z przeciwdziałaniem COVID-19. Co to oznacza? $\mathrm{W}$ art. 2 ust. 2 tej ustawy znajduje się enigmatyczne sformułowanie, że ilekroć w ustawie jest mowa o „przeciwdziałaniu COVID-19”, rozumie się przez to wszelkie

26 M. Kasiński, Część III - Legislacja terenowa. Dylematy działalności prawotwórczej wojewody. Wojewoda jako twórca prawa wewnętrznego, w: Legislacja administracyjna. Teoria, orzecznictwo, praktyka, red. Z. Duniewska, M. Stahl, 2012 [baza danych LEX].

27 P. Ruczkowski, Stan klęski żywiołowej. Komentarz, 2002 [baza danych Lex], Komentarz do art. 9.

28 Tamże.

29 M. Karpiuk, Zasady działania samorzadu lokalnego w czasie stanu klęski żywiołowej, Annales Universitatis Mariae Curie-Skłodowska 2014, z. 2, s. 57.

30 Ustawa z dnia 18 lipca 2002 r. o świadczeniu usług drogą elektroniczną, tekst jednolity: Dz. U. z 2020 r. poz. 344 . 
czynności związane ze zwalczaniem zakażenia, zapobieganiem rozprzestrzenianiu się, profilaktyką oraz zwalczaniem skutków, w tym społeczno-gospodarczych choroby. W literaturze zwraca się uwagę, że $\mathrm{w}$ ten sposób podkreślono zasadniczy cel ustawy, jakim jest stworzenie odrębnego od ustawy z dnia 5 grudnia $2008 \mathrm{r}$. o zapobieganiu oraz zwalczaniu zakażeń i chorób zakaźnych u ludzi zestawu regulacji mających na celu przeciwdziałanie zakażeniu wirusem SARS-CoV-2, zwalczanie zakażenia tym wirusem, zapobieganie rozprzestrzenianiu się wywołanej wirusem SARS-CoV-2 choroby zakaźnej COVID-19, a także zwalczanie jej skutków ${ }^{31}$. W wyniku obszernej nowelizacji ustawy z 7 października 2020 r. o zmianie niektórych ustaw w celu przeciwdziałania społeczno-gospodarczym skutkom COVID-1932 zawężono co prawda zakres do sformułowań: „w okresie obowiązywania stanu zagrożenia epidemicznego albo stanu epidemii, ogłoszonego z powodu COVID-19, oraz w okresie 3 miesięcy po ich odwołaniu”. Mimo że zdecydowano się na zawężenie okresu stosowania przepisów, zakres ten jest nadal szeroki i może być uznaniowy. Stworzono zatem konstrukcję „polecenia obowiązującego", łamiącego zasadę samodzielności samorządu terytorialnego na bazie pojęć niedookreślonych i nieostrych. Dodatkowo na podstawie art. 11h ust. 10 ustawy COVID-19 polecenia, o których mowa $\mathrm{w}$ art. 11h ust. 1-3 ustawy, nie mogą dotyczyć rozstrzygnięć co do istoty sprawy załatwianej w drodze decyzji administracyjnej, a także nie mogą dotyczyć czynności operacyjno-rozpoznawczych, dochodzeniowo-śledczych oraz czynności z zakresu ścigania wykroczeń. Wydaje się zatem, że intencją prawodawcy było stworzenie katalogu poleceń obowiązujących o charakterze celowym, a nie merytorycznym. Jednakże istnieje szeroki zakres spraw niezałatwianych w drodze decyzji administracyjnej, które mają także charakter merytoryczny. Ten zakres poszerza także ustawowe sformułowanie zawierające pojęcia niedookreślone: „wszelkie czynności związane ze zwalczaniem zakażenia, zapobieganiem rozprzestrzenianiu się, profilaktyką oraz zwalczaniem skutków, w tym społeczno-gospodarczych choroby".

Kolejny kontrowersyjny element omawianego polecenia obowiązującego to jego forma. Art. $11 \mathrm{~h}$ ust. 4 ustawy COVID-19 wskazuje, że polecenia te są wydawane $\mathrm{w}$ drodze decyzji administracyjnej i podlegają natychmiastowemu

31 M. Borski, Komentarz do art. 2 ustawy o szczególnych rozwiąaniach związanych z zapobieganiem, przeciwdziałaniem i zwalczaniem COVID-19, innych chorób zakaźnych oraz wywołanych nimi sytuacji kryzysowych, w: Tarcza antykryzysowa 1.0 - 4.0, ustawa o dodatku solidarnościowym i inne regulacje, jako szczególne rozwiązania $w$ prawie pracy, prawie urzędniczym i prawie ubezpieczeń społecznych zwiazane z COVID-19. Komentarz, red. K. Baran, 2020 [baza danych LEX].

32 Ustawa z 7 października 2020 r. o zmianie niektórych ustaw w celu przeciwdziałania społeczno-gospodarczym skutkom COVID-19, Dz. U. z 2020 r. poz. 1747. 
wykonaniu z chwilą ich doręczenia lub ogłoszenia oraz nie wymagają uzasadnienia. Tego rodzaju regulacji nie ma we wspomnianej ustawie o wojewodzie i administracji rządowej w województwie. Istotny kłopot interpretacyjny rodzi tutaj zatem charakter prawny owej „decyzji administracyjnej”, która przecież nie ma typowego charakteru i formy wynikającej z art. 106-107 Kodeksu postępowania administracyjnego ${ }^{33}$. W doktrynie stawia się tezę, że tego rodzaju zabieg jest niedopuszczalny ${ }^{34}$.

Nawiązując do relacji pomiędzy administracją rządową a samorządową, na uwagę zasługuje także treść art. $11 \mathrm{~h}$ ust. 13 ustawy, który stanowi, że zadania nałożone w trybie, o którym mowa w ust. 1, są realizowane przez jednostki samorządu terytorialnego jako zadania zlecone z zakresu administracji rządowej. Wynika z tego, że intencją ustawodawcy było to, aby w drodze „polecenia obowiązującego" mającego postać aktu kierownictwa można było zlecać zadania jednostkom samorządu terytorialnego. Jest to $\mathrm{z}$ kilku powodów nietrafiona konstrukcja prawna. Zgodnie z art. 166 ust. 1-2 Konstytucji RP zadania publiczne służące zaspokajaniu potrzeb wspólnoty samorządowej są wykonywane przez jednostkę samorządu terytorialnego jako zadania własne. Ponadto, jeżeli wynika to $\mathrm{z}$ uzasadnionych potrzeb państwa, ustawa może zlecić jednostkom samorządu terytorialnego wykonywanie innych zadań publicznych. Ustawa określa tryb przekazywania i sposób wykonywania zadań zleconych. Z Konstytucji RP wynika więc, że zadania własne i zlecone dotyczą jednostek samorządu terytorialnego, nie zaś wyodrębnionych bytów, jakimi są ich organy lub inne podmioty administrujące. Sposób zlecenia zadań został natomiast określony w ustawach ustrojowych związanych z samorządem terytorialnym. I tak np. zgodnie $\mathrm{z}$ art. 8 ust. 1 ustawy o samorządzie gminnym ${ }^{35}$ to ustawy mogą nakładać na gminę obowiązek wykonywania zadań zleconych z zakresu administracji rządowej, a także z zakresu organizacji przygotowań i przeprowadzenia wyborów powszechnych oraz referendów. Ponadto zadania z zakresu administracji rządowej gmina może wykonywać również na podstawie porozumienia z organami tej administracji. Przewiduje się więc dwie formy - podstawę ustawową lub porozumienie administracyjne. Brak jest tu gdziekolwiek podstawy do tego, aby podmioty

33 Ustawa z dnia 14 czerwca 1960 r. - Kodeks postępowania administracyjnego, tekst jednolity: Dz. U. z 2021 r. poz. 735 .

34 Zob. T. Chudziński, Komentarz do art. 11 ustawy o szczególnych rozwiązaniach związanych z zapobieganiem, przeciwdziałaniem i zwalczaniem COVID-19, innych chorób zakaźnych oraz wywołanych nimi sytuacji kryzysowych, w: Ustawa o szczególnych rozwiązaniach związanych z zapobieganiem, przeciwdziałaniem i zwalczaniem COVID-19, innych chorób zakaźnych oraz wywołanych nimi sytuacji kryzysowych. Komentarz, red. K. Szmid, 2020 [baza danych Legalis].

35 Ustawa z dnia 8 marca 1990 r. o samorządzie gminnym, Dz. U. z 2020 r. poz. 713, 1378 z późn. zm. 
administracji rządowej mogły jednostronnie i władczo wydawać polecenia obowiązujące w zakresie nakładania zadań zleconych.

W obrębie art. 11h ustawy COVID-19 należy zwrócić uwagę na zastosowanie poleceń obowiązujący w stosunku do przedsiębiorców. Na podstawie art. $11 \mathrm{~h}$ ust. 2 pkt 1 tego rodzaju polecenia może wydawać minister właściwy do spraw zdrowia oraz na podstawie art. $11 \mathrm{~h}$ ust. 3 Prezes Rady Ministrów. Zgodnie z dalszymi przepisami wykonywanie zadań objętych poleceniami wydanymi w stosunku do przedsiębiorców następuje na podstawie umowy zawartej z przedsiębiorcą, przez wskazanego w decyzji Szefa Kancelarii Prezesa Rady Ministrów, ministra albo wojewodę - w przypadku decyzji wydawanych przez Prezesa Rady Ministrów lub ministra albo wojewodę - w przypadku decyzji wydawanych przez ministra właściwego do spraw zdrowia. Analizując przepisy ustawy - wydaje się, że mają tu także zastosowanie wszystkie zasady związane z poleceniami obowiązującymi, o których mowa była wyżej, a wynikające z treści art. 11h. Jest to jednak błędna koncepcja, która przewiduje możliwość stosowania decyzji administracyjnej zarówno do podmiotów w ramach administracji publicznej, jak i podmiotów zewnętrznych.

Jaka jest zatem relacja pomiędzy poleceniem obowiązującym wynikającym $\mathrm{z}$ art. $11 \mathrm{~h}$ ustawy COVID-19 a aktami kierownictwa i pojęciem kierownictwa? Odpowiadając na to pytanie, trzeba posłużyć się podziałem adresatów (sfera wewnętrzna i zewnętrzna), którego jednak prawodawca nie zastosował.

Mając na uwadze pierwszą grupę (podmioty w ramach administracji publicznej), można przyjąć, że polecenia obowiązujące mają formę aktów kierownictwa, jednak nie są to polecenia służbowe związane - takie jak w przypadku zależności wynikającej z Kodeksu pracy. Czy tego rodzaju akt można zaklasyfikować do grupy tzw. aktów administracyjnych generalnych, które mają cechy aktu kierownictwa o charakterze wewnętrznym? W doktrynie wskazuje się, że istota generalnego aktu administracyjnego sprowadza się do tego, iż stanowi on środek prawny pozostający w dyspozycji podmiotów wykonujących administrację publiczną, który ma wszystkie cechy indywidualnego aktu administracyjnego z wyjątkiem cechy określania adresata (adresatów) tego aktu w sposób indywidualny ${ }^{36}$. Oznacza to, że kreowane nim normy postępowania nie określają adresatów wskazanych nim zachowań w sposób indywidualny, lecz - podobnie jak to jest w przypadku norm postępowania kreowanych aktami normatywnymi - określają adresatów wskazanych nim zachowań w sposób generalny ${ }^{37}$. Dzięki temu akt ten sprawia wrażenie aktu (formy działania) o charakterze pośrednim pomiędzy aktem normatywnym,

36 E. Szewczyk, M. Szewczyk, Generalny akt administracyjny, 2014 [baza danych LEX].

37 Tamże. 
a więc aktem stanowienia prawa, mocą którego ustanawiane są (z powołaniem się na autorytet państwa innego niż państwo podmiotu administracji publicznej czy jeszcze innego podmiotu dysponującego władztwem administracyjnym) generalne i abstrakcyjne normy postępowania przynależące do systemu źródeł prawa z jednej strony, z drugiej zaś indywidualny akt administracyjny, kojarzony tradycyjnie $\mathrm{z}$ aktem zawierającym normy indywidualno-konkretne i stanowiący akt stosowania, a nie stanowienia prawa ${ }^{38}$. Mając to na uwadze - konstrukcji przyjętej przez ustawodawcę w art. 11h ustawy COVID-19 nie sposób jednoznacznie zakwalifikować do kategorii aktów administracyjnych generalnych. Omawiana forma prawna zastosowana przez prawodawcę w art. 11h ustawy wymyka się także tutaj z przyjętej przez doktrynę siatki form działania administracji publicznej.

W przypadku drugiej grupy zaś (przedsiębiorcy) nie można mówić o aktach kierownictwa, gdyż relacja dotyczy podmiotów spoza administracji publicznej. Jednakże występuje tu forma nakazu odpowiedniego zachowania się kierowana do adresata w drodze decyzji administracyjnej.

\section{Zakończenie}

Jak wynika z powyższej analizy, ujęte w art. 11h ustawy COVID-19 tzw. „polecenie obowiązujące” wydaje się zupełnie wymykać doktrynie prawa administracyjnego, co związane jest przede wszystkim z błędnie wyrażonym przez prawodawcę zakresem podmiotowym i przedmiotowym normy prawnej. Nie jest to typowe polecenie służbowe ani akt o charakterze generalnym, brakuje tutaj bowiem jasno określonej zależności pomiędzy podmiotem wydającym a podmiotem zobowiązanym do realizacji takiego polecenia obowiązującego. W przypadku przedsiębiorcy tego rodzaju zależności jest w ogóle brak. Obszerne kłopoty interpretacyjne rodzi także wskazanie przez ustawodawcę, że polecenie obowiązujące ma formę decyzji administracyjnej, która w doktrynie prawa administracyjnego ma przecież swoje konkretne znaczenie oraz definicję.

Omawiane przepisy - które, jak się wydaje, miałyby stanowić lex specialis w stosunku do przepisów ustaw ustrojowych - nie przewidują ponadto żadnej formy kontroli związanej z wydawaniem poleceń obowiązujących w sferze wewnętrznej administracji publicznej. Nie mieszcząc się w rygorze indywidualnych aktów administracyjnych, nie podlegają zaskarżeniu jak w przypadku decyzji 
administracyjnych. Jedynym elementem kontrolnym jest tu art. 11 h ust. 12 ustawy COVID-19, zgodnie z którym właściwy minister może wstrzymać wykonanie poleceń i wystąpić $\mathrm{z}$ wnioskiem do Prezesa Rady Ministrów o rozstrzygnięcie sporu, przedstawiając jednocześnie stanowisko w sprawie. Brak jest natomiast przepisów regulujących wszczęcie takiego procesu ze strony podmiotów samorządowych.

Na koniec należy podnieść ważny aspekt dotyczący zależności między wojewodą a podmiotami znajdującymi się w jednostce samorządu terytorialnego. Regulacja polegająca na tym, że wojewoda może wydawać polecenia obowiązujące wszystkim podmiotom w samorządzie terytorialnym, wydaje się znacznie wykraczać poza konstytucyjne ramy i fundamentalną zasadę decentralizacji oraz samodzielności samorządu terytorialnego. Ustawa o szczególnych rozwiązaniach związanych z zapobieganiem, przeciwdziałaniem i zwalczaniem COVID-19, innych chorób zakaźnych oraz wywołanych nimi sytuacji kryzysowych natomiast znacząco rozszerza zakres przedmiotowy, posługując się pojęciami niedookreślonymi i własnymi definicjami, tylko na potrzeby tej konkretnej ustawy.

\section{Bibliografia}

Borski M., Komentarz do art. 2 ustawy o szczególnych rozwiązaniach związanych $z$ zapobieganiem, przeciwdziałaniem i zwalczaniem COVID-19, innych chorób zakaźnych oraz wywołanych nimi sytuacji kryzysowych, w: Tarcza antykryzysowa 1.0 - 4.0, ustawa o dodatku solidarnościowym i inne regulacje, jako szczególne rozwiąania $w$ prawie pracy, prawie urzędniczym i prawie ubezpieczeń społecznych związane z COVID-19. Komentarz, red. K. Baran, 2020 [baza danych LEX].

Cieślak Z., Zbiory zachowań w administracji państwowej. Zagadnienia podstawowe, Warszawa 1992.

Chudziński T., Komentarz do art. 11 ustawy o szczególnych rozwiązaniach zwiazanych z zapobieganiem, przeciwdziałaniem i zwalczaniem COVID-19, innych chorób zakaźnych oraz wywołanych nimi sytuacji kryzysowych, w: Ustawa o szczególnych rozwiazaniach zwiazanych $z$ zapobieganiem, przeciwdziałaniem i zwalczaniem COVID-19, innych chorób zakaźnych oraz wywołanych nimi sytuacji kryzysowych. Komentarz, red. K. Szmid, 2020 [baza danych Legalis].

Góralczyk W. jr., Kierownictwo w prawie administracyjnym, Warszawa 2016.

Haczkowska M., Komentarz do art. 93 Konstytucji RP, w: Konstytucja Rzeczypospolitej Polskiej. Komentarz, red. M. Haczkowska, 2014 [baza danych LEX].

Karpiuk M., Zasady działania samorządu lokalnego w czasie stanu klęski żywiołowej, Annales Universitatis Mariae Curie-Skłodowska 2014, z. 2. 
Kasiński M., Część III - Legislacja terenowa. Dylematy działalności prawotwórczej wojewody. Wojewoda jako twórca prawa wewnętrznego, w: Legislacja administracyjna. Teoria, orzecznictwo, praktyka, red. Z. Duniewska, M. Stahl, 2012 [baza danych LEX].

Malinowska I., Źródła prawa w Konstytucji RP z 1997 roku, Przegląd Sejmowy 2017, nr 6.

Rotkiewicz M., Ustawa o służbie cywilnej. Komentarz, 2018 [baza danych Legalis].

Ruczkowski P., Stan klęski żywiołowej. Komentarz, 2002 [baza danych LEX].

Sadowski P., Relacje administracji samorządowej i rządowej w świetle kompetencji marszałka województwa $i$ wojewody, Przegląd Prawa Publicznego 2019, nr 5.

Stankiewicz R., Koordynacja w prawie administracyjnym, Warszawa 2019.

Szewczyk E., Szewczyk M., Generalny akt administracyjny, 2014 [baza danych LEX].

Szyrski M., Kierownictwo $w$ samorzadzie terytorialnym. Analiza administracyjnoprawna, Warszawa 2015.

Tuleja P., Konstytucja Rzeczypospolitej Polskiej. Komentarz, 2019 [baza danych LEX].

Wiącek M., Komentarz do art. 93 Konstytucji RP, w: Konstytucja RP. Komentarz, red. M. Safjan, L. Bosek, 2016 [baza danych Legalis].

Zimmermann J., Prawo administracyjne, Warszawa 2012. 
